\title{
Charakterystyka fonetyczna /c/ we współczesnej polszczyźnie
}

Słow a klucze: uprzednienie welarnych, miękkość, relacja artykulacjaakustyka - percepcja

\section{Wstęp}

W pracach z zakresu fonetyki i fonologii języka polskiego podstawowe warianty realizacyjne fonemu /c/1 określane sa jako postpalatalne ${ }^{2}$ (Wierzchowska 1980; Sawicka 1995; Ostaszewska, Tambor 2000). Artykulacyjnie, akustycznie i percepcyjnie niewiele więc powinno różnić tak scharakteryzowane [c] od uprzednionego wariantu realizacyjnego fonemu $/ \mathrm{k} /$, czyli od [ $\mathrm{k}_{+}$] np. z wyrazów kelner, weekend czy Okęcie o prewelarnym, a w wymowie

${ }^{1}$ Interpretacja fonologiczna i dystrybucja fonemu /c/ zgodna z propozycją I. Sawickiej (Sawicka 1995), por. dla innych języków przypis 9. W pracy uwzględniono bezdźwięczne zwarte [c], wyłączając dźwięczny odpowiednik, tj. [ł], m.in. z uwagi na licznie reprezentowane realizacje aproksymowane.

2 Zgodnie z przeważającą częścią literatury przedmiotu obszary podniebienia, których nazwa poprzedzona jest przedrostkami pre-, medio- i post-, interpretowano jako część przednią, środkową i tylną podniebienia twardego lub miękkiego (por. Dukiewicz 1996: 27). Używana terminologia, tj. prepalatum, mediopalatum, prewelum nie ma jednak jednoznacznego odzwierciedlenia w podziałach anatomicznych podniebienia, stąd w literaturze odpowiadają im niekiedy różniące się wielkością obszary (por. Koneczna 1934: 103; Recasens, Fontdevila, Pallarès 1994: 75). 
niektórych mówców nawet bardziej przednim miejscu artykulacji. Niewielkiej różnicy między realizacjami fonemów /c/ i / k/, jaką postuluje tradycja językoznawstwa polonistycznego i na jaką wskazuje większość dostępnych dla języka polskiego palato- i rentgenogramów (Koneczna, Zawadowski 1951; Dłuska 1986; Wierzchowska 1980), przeczą wyniki percepcyjnej klasyfikacji kontoidów języka polskiego (Łobacz 1989), sytuujące [c] w grupie z prepalatalnymi: [n], [ढ], [z], [tढ], [d̂]], jak i wyniki analizy akustycznej przeprowadzonej przez autorkę, wskazujące, że we współczesnej polszczyźnie standardowej, przynajmniej w jej odmianie południowej, zwarcie języka z podniebieniem podczas artykulacji [c] dokonuje się w przeważającej liczbie realizacji w przedniej części podniebienia twardego, tj. w obszarze prepalatum lub części mediopalatum bezpośrednio znajdującej się za prepalatum (83,0\% realizacji; pięćdziesięciu czterech mówców pochodzących z obszaru dialektu małopolskiego), nie zaś w tylnej części podniebienia twardego, tj. w postpalatum ( $1,1 \%$ realizacji dla tej samej grupy mówców). Podobny odsetek przednich realizacji, czyli prepalatalnych i przedniomediopalatalnych, oraz tylnych, czyli postpalatalnych, uzyskano dla materiałów z Gwar polskich. Przewodnik multimedialny, dokumentujących wymowę dialektalną (odpowiednio: realizacje prepalatalne i przedniomediopalatalne - 78,9\% wobec 3,9\% postpalatalnych; w analizie uwzględniono wymowę siedemdziesięciu pięciu osób z trzydziestu dziewięciu gwar³).

\section{Założenia metodologiczne}

W celu wyznaczenia miejsca artykulacji podstawowego wariantu realizacyjnego fonemu /c/ jego strukturę akustyczną opisano za pomocą dwóch parametrów częstotliwościowych, a następnie dokonano artykulacyjnej interpretacji sporządzonego opisu. Opis akustyczny, jak i jego uproszczona interpretacja artykulacyjna zostały przeprowadzone odpowiednio do założeń teorii modelowania artykulacji na podstawie analizy sygnału akustycznego, zaproponowanej przez G. Fanta i rozwijanej m.in. przez K. Stevensa (Fant 1960; Stevens 2000). Wybór sposobu wyznaczania miejsca artykulacji na

3 Dla dialektu małopolskiego przeanalizowano materiały z 16 gwar, dla dialektów mazowieckiego i wielkopolskiego z 10 gwar dla każdego dialektu, a dla dialektu śląskiego z 3 gwar. Poza gwarami śląskimi i wielkopolskimi w przeprowadzonej analizie gwarę reprezentowało 2-3 mówców. 
podstawie zarejestrowanego sygnału mowy wynika z możliwości uwzględnienia w tak prowadzonych badaniach większej liczby mówców (w przypadku badań bezpośrednich, wykonywanych, przykładowo, przy użyciu elektromagnetycznego artikulografu (EMA) lub elektropalatografu (EPG), zwykle poddawana jest analizie wymowa co najwyżej kilku osób), nadto, pozwala on wykorzystać dane zawarte w nagraniach zgromadzonych w ramach innych, w tym wcześniejszych, badań i prowadzić, przykładowo, analizę wybranej artykulacji w kolejnych pokoleniach lub socjologicznie różnych grupach użytkowników tego samego języka, jak też porównywać elementy systemu fonetycznego genetycznie bliskich sobie języków.

Uwzględnione $\mathrm{w}$ opisie akustycznym parametry częstotliwościowe to maksima energii sygnału wyznaczone dla plozji $\left(f_{p}\right)$ i następującego po niej komponentu szumowego $\left(\mathrm{f}_{\mathrm{sz}}\right)$. Strukturę kontoidów zwartych, obejmującą zwarcie (zw), plozję (p) i komponent szumowy (sz) aspiracji lub afrykacji, przyjęto za W. Jassemem ${ }^{4}$ (Jassem 1973: 231-242). W odniesieniu do realizacji z wielokrotnymi plozjami maksimum plozji wyznaczano uwzględniając wszystkie składowe i traktując je łącznie 5 . Jako aspirację klasyfikowano szum o bardziej wyrównanej charakterystyce, występujący również w zakresie niskich częstotliwości, zaś jako afrykację - szum analogiczny do komponentu afrykat, występujący wyłącznie w paśmie wyższych częstotliwości ${ }^{6}$

${ }^{4}$ Inaczej strukturę kontoidów zwartych opisuje m.in. B. Wierzchowska, wyróżniając implozję, plozję i eksplozję zakończoną przydechem (Wierzchowska 1980: 41, 43).

5 W literaturze przedmiotu przy opisach welarnego [k] wzmiankowane są, często na marginesie głównych rozważań, wielokrotne plozje (Fant 1960: 179; Łobacz 1996: 134; Stevens 2000: 369-370; Moosmüller 2007: 142). Ich powstawanie K. Stevens wyjaśnia na gruncie aerodynamiki (Stevens 2000: 329-330). Kolejne zwarcia nie muszą - na co wskazują przykłady przedstawione w dalszej części pracy - następować w tym samym obszarze podniebienia.

${ }^{6}$ Klasyfikacja ta nawiązuje do podziału kontoidów zwartych na nieaspirowane z jednej strony oraz z drugiej - aspirowane i afrykatyzowane (Cho, Ladefoged 1999). Z kolei wg terminologii, którą posługują się G. Fant i K. Stevens, frykcja to szum, którego źródłem jest szczelina powstała w jamie ustnej po oderwaniu się języka od miejsca zwarcia, zaś aspiracja to szum, wytwarzany przez szczelinę między rozsuniętymi wiązadłami głosowymi, powstały bezpośrednio przed pierwszym pozytywnym przejściem sygnału przez zero, świadczącym o wznowieniu drgań wiązadeł, stąd aspiracja to zwykle krótki, kilkumilisekundowy segment dla kontoidów niespirowanych (m.in. Stevens 2000: 347, 351, 358-359, 460). Przewężenie kanału głosowego w jamie ustnej determinuje jednak w większym stopniu charakterystykę komponentu szumowego następującego po plozji niż przestrzeń powstała pomiędzy rozsuniętymi wiązadłami głosowymi. 
(Moosmüller, Ringen 2004: 45-46). Częstotliwościowo parametryzowano zatem tę część kontoidów zwartych, którą określa się jako $\mathrm{VOT}^{7}$ (Keating, Mikoś, Ganong 1981: 1261; Jessen 2002: 156-157). W akustycznym opisie wariatów realizacyjnych fonemu /c/ uwzględniono również dwa parametry czasowe - czas zwarcia $\left(\mathrm{t}_{\mathrm{zw}}\right)$ i $\operatorname{czas} \mathrm{VOT}^{8}\left(\mathrm{t}_{\mathrm{vot}}\right)$ (por. rys. 1.).

Uproszczona interpretacja artykulacyjna opisu akustycznego zaproponowanego dla realizacji fonemu /c/ możliwa jest z uwagi na to, że maksima energii sygnału poszczególnych faz artykulacji, odpowiednio plozji i komponentu szumowego aspiracji lub afrykacji, skorelowane są z częstotliwością rezonansową - jeśli przyjać najprostszy model - jednostronnie ograniczonej tuby, jaka powstaje w przedniej części jamy ustnej i którą od tyłu ogranicza bądź zwarcie języka z podniebieniem (w przypadku plozji), bądź szczelina o niewielkim przekroju (w przypadku komponentu szumowego); tuba ta obejmuje przestrzeń od warg po miejsce największego przewężenia kanału głosowego (Fant 1960: 73; Keating, Lahiri 1993: 96; Stevens 2000: 373). Miejsce największego przewężenia kanału głosowego, a dokładniej środek tego przewężenia, odpowiada miejscu artykulacji - dla kontoidów zwartych jest to miejsce zwarcia języka z podniebieniem9. Uwzględniając relacje mię-

Mniejszą więc uwagę w niniejszej pracy poświęcono szumowi wytworzonemu w obrębie głośni. Nadto, analizując sygnał mowy, trudno rozdzielić wpływ obu źródeł szumu na charakterystykę segmentu następującego po plozji, zwłaszcza że ich oddziaływanie jest czasowo współbieżne. Komponent szumowy nazywany w niniejszej pracy aspiracją lub afrykacją definicyjnie nie odwołuje się więc do umiejscowienia wytwarzającego go źródła. Łącznie oba typy szumów rozpatruje także m.in. B. Wierzchowska, nazywając je zbiorczo przydechem (Wierzchowska 1980: 43). Podobnie czyni H. Koneczna, odnosząc się równocześnie do miejsca artykulacji przydechu, które lokalizuje jednoznacznie w jamie ustnej, nie zaś w głośni (Koneczna 1934: 90-91).

7 VOT jako część kontoidów zwartych, obejmująca plozję i następujące po niej ewentualne komponenty szumowe aż po pierwsze tzw. pozytywne przejście sygnału przez zero, wyznaczające początek segmentu wokoidalnego połączenia -CV-, odpowiada w innej terminologii, pozytywnemu VOT (por. dla języka polskiego Rojczyk 2009).

8 Analizę akustyczną prowadzono przy użyciu oprogramowania STx opracowanego przez Instytut Akustyki Austriackiej Akademii Nauk. Materiał nagraniowy, który poddano analizie akustycznej, został zgromadzony m.in. w ramach projektu realizowanego przez autorkę w Instytucie Ekspertyz Sądowych w Krakowie, a także został zaczerpnięty z przewodnika multimedialnego opracowanego pod redakcją H. Karaś.

${ }_{9} \mathrm{~W}$ wielu językach, np. angielskim, szwedzkim czy katalońskim, [c] przed samogłoskami przednimi, w tym [i], opisywane jest jako uprzedniony wariant fonemu $/ \mathrm{k} /$. Miejsce artykulacji kontoidu przed [i] w tych językach jest znacznie przesunięte w stosunku do welum i sytuuje się w odległości około $2,5 \mathrm{~cm}$ od zębów przednich, podczas 
dzy długością jednostronnie ograniczonej tuby, częstotliwością rezonansową i prędkością rozchodzenia się dźwięku w powietrzu o temperaturze około $37^{\circ} \mathrm{C}$, wyznaczano długość przedniej tuby, czyli de facto estymowano miejsce zwarcia lub szczeliny. W niniejszej pracy wyznaczano zarówno miejsce zwarcia języka z podniebieniem (na podstawie maksimum plozji), jak i miejsce, w którym powstaje szczelina będąca źródłem następującego po plozji szumu (na podstawie maksimum komponentu szumowego).

\section{Omówienie wyników}

Podstawowy wariant realizacyjny palatalnego fonemu /c/ powinien być artykulacyjnie i akustycznie jednorodny. Artykulacyjnie oznacza to, że miejsce zwarcia języka z podniebieniem, jak i szczelina powstała następnie między artykulatorami, powinny formować się w tym samym obszarze. Akustycznie jednorodność podstawowego wariantu realizacyjnego fonemu /c/ powinna z kolei przejawiać się tym, że maksima energii sygnału dla kolejnych faz artykulacji - plozji i szumu, sytuują się w tym samym zakresie częstotliwości. Nadto, żeby realizację [c] można było sklasyfikować percepcyjnie jako jednoznacznie miękką, jej artykulacja musi dokonywać się - na co wskazują wyniki testów odsłuchowych przeprowadzonych przez autorkę - w obszarze prepalatum lub przedniej części mediopalatum. Akustycznie odpowiada to maksimom plozji i komponentu szumowego występującym w zakresie około 2600-4500 Hz. Realizacje jednorodne akustycznie o maksimach niższych niż około $2600 \mathrm{~Hz}$ oceniane są percepcyjnie jako półmiękkie ${ }^{10}$ (przy maksimach w zakresie około 2200-2600 Hz) lub twarde (poniżej około $2200 \mathrm{~Hz}$ ) i wówczas wskazywane jest ich całkowite podobieństwo do [k].

\subsection{Realizacje niejednorodne}

Nie wszystkie $\mathrm{z}$ analizowanych realizacji wariantu podstawowego fonemu /c/ w wymowie osób posługujących się standardową polszczyzną, w jej

gdy wariant podstawowy / k/ artykułowany jest w odległości około 5-6 cm, co odzwierciedla się w charakterystyce częstotliwościowej obu wariantów - częstotliwość rezonansowa wariantu przedniego mieści się w zakresie 3-3,5 kHz, zaś welarnego - poniżej $2 \mathrm{kHz}$ (por. Stevens 2000: 365-375).

10 Percepcyjna kategoria półmiękkości została użyta do opisu realizacji fonemów /c/ i /ł/ m.in. w Osowicka-Kondratowicz, Serowik 2007. 
odmianie południowej, można było sklasyfikować jako jednorodne akustycznie i artykulacyjnie. Obserwowana niejednorodność akustyczna [c] świadczy o różnym stopniu uprzednienia (spalatalizowania) ${ }^{11}$ kolejnych faz artykulacji - plozja słabiej upodobniona do prawostronnego kontekstu palatalnego następnika, tj. [i], mająca niższą wartość maksimum, co wskazuje na, relatywnie rzecz ujmując, bardziej tylne miejsce zwarcia języka z podniebieniem, oraz wyraźniej upodobniony do palatalnego [i] komponent szumowy, o wyższej wartości maksimum, a zatem i wytwarzany przez szczelinę zlokalizowaną w bardziej przedniej części jamy ustnej niż miejsce zwarcia.

Wariantywność realizacyjną artykulacji reprezentujących wariant podstawowy fonemu /c/ w wymowie osób posługujących się standardową polszczyzną, pochodzących z obszaru dialektu małopolskiego, przedstawiono w tabeli 1 . z uwzględnieniem wariantów jednorodnych i różniących się stopniem spalatalizowania kolejnych faz artykulacji. W tabeli 2. zamieszczono wyniki dla wymowy uwarunkowanej dialektalnie.

Tab. 1. Procentowy udział wariantów realizacyjnych fonemu /c/ w wymowie pięćdziesięciu czterech mówców pochodzących z obszaru dialektu małopolskiego, posługujących się standardową polszczyzną

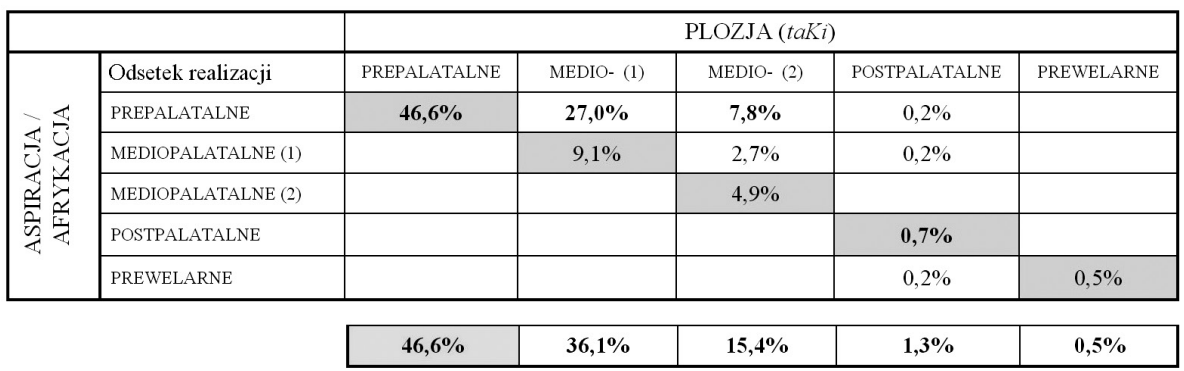

Źródło: opracowanie własne.

11 D. Recasens i A. Espinoza palatalizacją welarnych nazywają zmianę miejsca ich artykulacji z welarnej na bardziej przednią, np. mediopalatalną, prepalatalną czy dziąsłową. Odróżniają jednocześnie ten proces od zmiękczenia welarnych (ang. velar softening), w wyniku którego zwarto-wybuchowe stają się afrykatami (zmiana sposobu artykulacji). Według nich palatalizacja jest niezbędnym etapem w rozwoju welarnych zwartych w palatalne afrykaty (Recasens, Espinosa 2009: 190). W pracach dotyczących języka polskiego, oba procesy: uprzednienia się welarnych, jak i ich przejścia w afrykaty, zwykło się nazywać palatalizacją (Koneczna 1965; Długosz-Kurczabowa, Dubisz 2001). 
W głównej tabeli kolorem szarym wypełniono pola odnoszące się do akustyczno-artykulacyjnie jednorodnych realizacji, a pogrubioną czcionką wskazano najliczniejsze realizacje o określonym miejscu artykulacji (z uwzględnieniem miejsca zwarcia i szczeliny). Dodatkowo, w dolnej tabeli podano łączny odsetek realizacji o prepalatalnym, mediopalatalnym, postpalatalnym i prewelarnym miejscu artykulacji [c], wyznaczonym z uwagi na miejsce zwarcia języka z podniebieniem.

Tab. 2. Procentowy udział wariantów realizacyjnych fonemu /c/ w wymowie siedemdziesięciu pięciu mówców, reprezentujących trzydzieści dziewięć gwar i odpowiednio, cztery dialekty: małopolski, wielkopolski, mazowiecki i śląski

\begin{tabular}{|l|c|c|c|c|}
\hline \multicolumn{1}{|c|}{$\boldsymbol{k} \boldsymbol{i}$} & D. MALOPOLSKI & D. WIELKOPOLSKI & D. MAZOWIECKI & D. ŚLASKI \\
\hline PREPALATALNE & $\mathbf{5 5 , 7}$ & $\mathbf{4 8 , 2}$ & 26,4 & $\mathbf{1 5 , 4}$ \\
\hline MEDIOPALATALNE (1) & $\mathbf{2 7 , 3}$ & $\mathbf{3 6 , 5}$ & $\mathbf{3 8 , 0}$ & $\mathbf{4 2 , 3}$ \\
\hline MEDIOPALATALNE (2) & $\mathbf{1 3 , 4}$ & $\mathbf{8 , 2}$ & 26,6 & $\mathbf{3 8 , 5}$ \\
\hline POSTPALATALNE & $\mathbf{3 , 1}$ & 4,7 & $\mathbf{4 , 7}$ & 3,8 \\
\hline PREWELARNE & 0,3 & $\mathbf{1 , 2}$ & 0,2 & $\mathbf{0 , 0}$ \\
\hline
\end{tabular}

Źródło: opracowanie własne

$\mathrm{W}$ tabeli 2. pogrubioną czcionką wskazano najliczniejsze realizacje o określonym miejscu artykulacji, wyznaczonym w odniesieniu do miejsca zwarcia języka z podniebieniem.

Różnice w stopniu spalatalizowania poszczególnych elementów struktury podstawowych wariantów realizacyjnych fonemu /c/ - większym komponentu szumowego i mniejszym plozji, wskazują na potencjalne możliwości do dalszego uprzednienia się (palatalizowania) kontoidu. Argumentu za taką interpretacją ewentualnego rozwoju niejednorodnych, acz znacznie już uprzednionych [c] dostarcza analiza realizacji z wielokrotnymi plozjami, pozwalając jednocześnie postrzegać je jako fazę pośrednią między wariantami jednorodnymi o różnym stopniu uprzednienia miejsca ich artykulacji (por. rys. 2. i 3.). Przykładowo, analizując realizację [c] z wyrazu taki (rys. 2.), należy odnotować relatywnie niskie wartości maksimów dwóch pierwszych plozji - odpowiednio $2106 \mathrm{~Hz}$ i $2128 \mathrm{~Hz}$, które wskazują na postpalatalne miejsce zwarcia języka z podniebieniem. Maksimum trzeciej plozji wynosi 
$4365 \mathrm{~Hz}$ i jest ono bliskie maksimum komponentu szumowego (afrykacji) $4497 \mathrm{~Hz}$. Zwarcie języka z podniebieniem przy trzeciej plozji następuje w obszarze prepalatum, tam także po oderwaniu się języka tworzy się szczelina będąca źródłem afrykacji. Najbardziej zatem spalatalizowany (uprzedniony) jest komponent szumowy, bezpośrednio sąsiadujący z palatalnym [i], nieco słabiej trzecia plozja poprzedzająca afrykację, w najmniejszym zaś stopniu upodobnienie objęło dwie pierwsze plozje.

Wariantywność realizacyjna [c], jaką można obserwować w prawostronnym kontekście [i] w wymowie pięćdziesięciu czterech mówców posługujących się standardową polszczyzną, pochodzących z obszaru dialektu małopolskiego, dowodzi, że obok mówców używających wyłącznie prepalatalnych realizacji [c] są i tacy, w wymowie których poświadczone są dwa lub trzy warianty [c] o nieco innej charakterystyce akustyczno-artykulacyjnej (por. rys. 3.). Przykładowo, mówca WW posługuje się zarówno względnie jednorodnymi realizacjami prepalatalnymi $(16,7 \%)$ i mediopalatalnymi (25,0\%), jak i realizacjami pośrednimi, o plozji i komponencie szumowym różniącym się stopniem spalatalizowania $(58,3 \%$; zwarcie języka z podniebieniem na pograniczu prepalatum i przedniej części mediopalatum, szczelina w prepalatum). Trójwariantową wymowę [c] odnotowaną dla mówcy WW można jednocześnie potraktować jako ilustrację kierunku i chronologii dotychczasowego i ewentualnie dalszego rozwoju realizacji fonemu /c/.

\subsection{Uwarunkowanie nastepnikiem}

Wariantywność realizacyjna fonemu /c/ wynika z socjologicznie określonych nawyków wymawianiowych, tj. tendencji do posługiwania się takimi a nie innymi wariantami, różniącymi się także częstością użycia (por. wcześniej omawiany przykład mówcy WW). W mniejszym stopniu i w sposób niesystemowy wariantywność realizacyjna fonemu /c/ zdeterminowana jest we współczesnej polszczyźnie przez czynniki językowe, np. prawostronny kontekst wokaliczny, położenie względem sylaby akcentowanej, szybkie lub wolne tempo mówienia czy stopień oficjalności wypowiedzi. Do takich wniosków skłaniają wyniki analizy [c] w wymowie pięćdziesięciu czterech mówców posługujących się standardową polszczyzną, pochodzących z obszaru dialektu małopolskiego. Dla przykładu, opis akustyczno-artykulacyjny kontoidu [c], zdefiniowanego w układzie $-\mathrm{V}_{1} \mathrm{CV}_{2}$ - jako segment między 
ostatnim okresem poprzedzającego go wokoidu $\left(\mathrm{V}_{1}\right)$ i tzw. pierwszym pozytywnym przejściem sygnału przez zero, wskazującym na początek prawostronnego kontekstu wokoidalnego $\left(\mathrm{V}_{2}\right)$, nie wykazuje systematycznej, a zatem i systemowej, różnicy z uwagi na jakość fonemu samogłoskowego stanowiącego jego prawostronny kontekst - [c] z wyrazów kiosk, kiper i kie$d y$ są takie same akustycznie, a także artykulacyjnie i percepcyjnie. Powyższy wniosek uprawniony jest dla leksemów występujących w języku polskim, jak i logatomów o fonologicznej strukturze $/ \mathrm{cVs}^{12} \mathrm{i} / \mathrm{cV} 6 /$ (por. rys. 4. i 5.).

Tego, że prawostronny kontekst wokaliczny może stanowić czynnik systematycznie i systemowo różnicujący artykulację genetycznych kontynuantów welarnego [k], dowodzi porównanie wymowy osób posługujących się standardową polszczyzną z wymową użytkownika odmiany standardowej języka rosyjskiego. Systemowość zróżnicowania artykulacji kontoidu z uwagi na następnik odnotowano zarówno dla leksemów ze słownika języka rosyjskiego, jak i logatomów tożsamych z wypowiadanymi przez użytkowników języka polskiego (por. rys. 6.).

\subsection{Tzw. j postulowana $w$ interpretacjach fonologicznych}

Przyczyn braku systemowego zróżnicowania w standardowej polszczyźnie analizowanego kontoidu ze względu na prawostronny kontekst wokaliczny należy poszukiwać w strukturze następującego po nim wokoidu, a dokładniej w tej jego części, która bezpośrednio występuje po [c]. Parametryzując początkową część wokoidu za pomocą częstotliwości formantowych, stwierdzono, że są one adekwatne do charakterystyki formantowej wariantów realizacyjnych fonemu /i/, a wówczas, gdy po [c] występuje [i], to część początkowa wokoidu ma nawet bardziej przednią i zarazem bardziej zamkniętą artykulację aniżeli dalsze fazy [i]. Prawidłowość tę odnotowano w leksemach języka polskiego i logatomach (por. rys. 5.). W przywoływanym wcześniej przykładzie wymowy użytkownika standardowej odmiany języka rosyjskiego nie tylko kontoidy, ale także początkowa część wokoidów wykazują zróżnicowanie w zależności od prawostronnego kontekstu (por. rys. 6.); opis akustyczny początkowej części wokoidów dla języka rosyjskiego, sta-

12 Logatom kies, na co zwrócił uwage jeden z recenzentów, jest homonimiczny z formą D. 1. mnogiej wyrazu kiesa. 
nowiących prawostronny kontekst realizacji fonemu [k], jest analogiczny do opisu początku wokoidów następujących w języku polskim, np. po [ [ढढ] i [6].

Analiza wymowy niestandardowej, z twardymi w ocenie audytywnej realizacjami fonemu /c/, tj. których komponent szumowy wytwarzany jest w obszarze postpalatum lub przylegającej do niego tylnej części mediopalatum (maksima szumu poniżej $2600 \mathrm{~Hz}$ ), każe dokonać zastrzeżenia co do charakterystyki początkowej części wokoidu, stanowiącego prawostronny kontekst [c], którą w odniesieniu do wymowy standardowej opisano powyżej jako adekwatną do charakterystyki formantowej podstawowego wariantu realizacyjnego fonemu /i/. Przy relatywnie tylnej artykulacji komponentu szumowego [c] (postpalatum lub tylna część mediopalatum) początkowa cześć wokoidu nie osiąga prepalatalnej artykulacji właściwej podstawowemu wariantowi realizacyjnemu fonemu /i/ (por. Trawińska 2009). Jego charakterystyka formantowa jest bliższa wariantom realizacyjnym fonemów /í / lub / $/$ /. $\mathrm{Z}$ tego też względu przy tylnych artykulacjach realizacji fonemu /c/ w ogóle lub bardzo słabo percypowany jest segment przejściowy, tzw. $j$. Interpretowanie tzw. wydzielania się $j$ - pomijając z czego, przy takiej konceptualizacji, następuje wydzielanie się $j, \mathrm{tj}$. z kontoidu czy wokoidalnego następni$\mathrm{ka}$ - jako przesłanki wskazującej na depalatalizację /c/ jest nieuprawnione (por. także Łobacz 1982; Sawicka, Grzybowski 1999). Niewłaściwe są także, jeśli kierować się wyłącznie argumentami fonetycznymi, dla standardowej wymowy, przynajmniej w jej odmianie południowej, próby fonologizowania grup ortograficznie zapisywanych kie/gie jako reprezentacji /kje/, /gje/. Segment przejściowy, tzw. $j$, odnotowywany jest akustycznie i percepcyjnie przy standardowej wymowie realizacji /c/, tj. przy realizacjach o prepalatalnym lub przedniomediopalatalnym miejscu zwarcia języka z podniebieniem.

Analiza niestandardowej wymowy z twardymi w ocenie audytywnej realizacjami fonemu /c/ wskazuje nie tylko na odmienną niż w wymowie standardowej charakterystykę kontoidu i początkowej części wokoidu, ale także zasadniczo na bardziej tylną artykulację przednich wokoidów, co jest także znaczące dla percepcji realizacji fonemu /i/, jak i całej grupy.

Taka sama, podobna jak dla [i], charakterystyka formantowa początkowej części wokoidu następującego w wymowie standardowej po [c], niezależna od tego, jakiego fonemu samogłoskowego wariant realizacyjny stanowi pra- 
wostronny kontekst fonetyczny kontoidu, tj. czy jest to [i], [ع], [a] czy [o] $]^{13}$, z punktu widzenia fonetyki jest argumentem do jednakowego traktowania struktury grup ki, kie i kia, kio, nie rozstrzygając, czy reprezentacja fonologiczna tych grup powinna być, pomijając połączenia $k i$, typu /ce/ czy /cje/. Niewystarczające do rozstrzygnięcia co do reprezentacji fonologicznej wydają się być argumenty natury audytywnej. To, że przed samogłoskami tylnymi segment przejściowy, tzw. $j$, jest wyraźniej percypowany, w głównej mierze jest konsekwencją różnego dystansu artykulacyjnego, jaki dzieli w akomodującej wymowie właściwej językowi polskiemu np. prepalatalne [c] od przednich: $[\mathrm{i}],[\dot{i}],[\varepsilon]^{14} \mathrm{i}$ od tylnych $[\propto],[\mathrm{o}],[\mathrm{u}]$. Różnice zaś związane $\mathrm{z}$ wariantywnością/E/, czyli bardziej zamkniętymi lub otwartymi realizacjami, zdają się nie pozostawać bez związku z opisywanymi w literaturze odpowiednio, brakiem lub percepcją tzw. $j$.

Charakterystyka akustyczna początku wokoidów dowodzi, że samogłoski właściwe występujące po [c] poprzedza analogiczny segment przejściowy. Wysuwany jako argument za fonologizowaniem tzw. $j$ po [c] brak analogicznego segmentu przejściowego po np. [โढ]], także o przedniej, prepalatalnej artykulacji, można tłumaczyć relatywnie długim segmentem VOT dla [โढ] $\mathrm{w}$ porównaniu z [c] przy jednocześnie krótszym wokoidzie (dla [tढ] VOT stanowi 0,5 długości wokoidu, zaś dla [c] $0,3^{15}$ ). Zgodnie z poglądem $\mathrm{H}$. Konecznej długi, posługując się terminologią nieco późniejszą względem jej badań, VOT $\left[\hat{t}_{\epsilon}\right]$ to rezultat wchłonięcia przez kontoid najbardziej uprzednionej części wokoidu (Koneczna 1965: 32, 123). Poprawność takiego wnioskowania potwierdzają wyniki eksperymentu, w którym w odniesieniu do wcześniej omawianych logatomów dokonano modyfikacji struktury /cV-/, dopasowując ją do proporcji właściwych dla / $6 \widehat{6 V}-/$, tj. skrócono długość wokoidu o początkową część, traktując ją jako część kontoidu. Opis formantowy początkowej części wokoidów następujących po [c] dla tak zmodyfikowanych grup /cV-/ okazał się być zgodny z opisem dla połączeń /

13 W przeprowadzonej analizie nie uwzględniono przykładów połączeń kiu.

14 A zwłaszcza wariant podwyższony i uprzedniony, [ $\left.\varepsilon_{1}\right]$ jaki występuje w obustronnym kontekście palatalnym, np. wyrazie higieniczny, i w związku z tym bardzo łatwo o monoftongizację segmentu przejściowego i [₹] ]. Stąd m.in. w higieniczny tzw. $j$ może nie być percypowana lub percypowana słabo w porównaniu z wyrazem higiena.

15 Wyniki uśrednione na podstawie analizy logatomów wymawianych przez cztery osoby, posługujące się standardową polszczyzną, pochodzące z obszaru dialektu małopolskiego. 
Poszukując ewentualnych argumentów akustyczno-artykulacyjnych, wspierających wybór typu/ce/ lub /cje/ jako reprezentacji fonologicznych grup ki, kie, kia, kio, przeanalizowano realizację [c] i jego prawostronny kontekst wokoidalny w wyrazach religia i Religa, koncentrując się na wymówieniach form D. $1 p^{16}$. Porównanie wyrazów religii i Religi, umieszczonych w zdaniach, jak i odczytywanych z listy wyrazowej, wymówionych przez cztery osoby posługujące się standardową polszczyzną, pochodzące z obszaru dialektu małopolskiego, wskazuje na neutralizację. Neutralizacja dotyczy akustyczno-artykulacyjnej charakterystyki kontoidu: maksimów plozji i komponentu szumowego, a także długości VOT oraz wokoidu: charakterystyki formantowej i długości. Podczas odczytywania listy wyrazowej dwaj mówcy próbowali różnicować religii i Religi, przy czym stosowali odmienne strategie - jeden, wymawiając religii, wydłużał VOT kontoidu przy zachowaniu porównywalnej dla obu wyrazów długości wokoidów, drugi zaś przy religii wydłużał wokoid, nie różnicując długości VOT kontoidu. Czas, o jaki segmenty były wydłużane, w obu przypadkach był porównywalny i wynosił około $30 \mathrm{~ms}$. Postulowane różnice reprezentacji fonologicznych form typu religii i Religi wydają się nie mieć na poziomie fonetycznym dostatecznie przekonującego uzasadnienia, zwłaszcza dla wymowy młodego pokolenia użytkowników współczesnej polszczyzny.

\subsection{Stopień uprzednienia $/ k /$ pod wplywem $/ j /$ na granicy wyrazowej}

Z uwagi na doniesienia literaturowe o słabnięciu akomodacyjnej wymowy w języku polskim poddano również analizie występujące na granicy wyrazowej połączenia /-k $\mathrm{k}_{\smile} \mathrm{j}-/$. Przeanalizowano dwieście trzydzieści pięć realizacji fraz tak jak ty i park jesienny wymówionych co najmniej trzykrotnie przez czterdziestu ośmiu mówców posługujących się standardową polszczyzną, pochodzących z obszaru dialektu małopolskiego ${ }^{17}$ (por. tab. 3.). Aż $75,3 \%$ realizacji stanowiły takie, w których upodobnienie było na tyle silne, że wyraźnie uprzedniało artykulację welarnego / k/, sytuując ją w przedniej części podniebienia twardego i zrównując na poziomie fonetycznym z pod-

16 Wyboru dokonano kierując się kryterium częstości użycia i jednocześnie brakiem adekwatnej pary minimalnej z bezdźwięcznym [c].

17 Mówcy pochodzili z Pogranicza Wschodniego Starszego o tzw. ubezdźwięczniającej fonetyce międzywyrazowej. 
stawowym wariantem realizacyjnym fonemu /c/. Większość analizowanych połączeń należałoby zatem transkrybować jako [-c ${ }_{-}$-], około 18,8\% jako $\left[-k^{j} \smile j-\right]$ i około $6,0 \%$ jako $\left[-k_{\smile j-} j\right.$.

Tab. 3. Procentowy udział różniących się artykulacyjnie realizacji spalatalizowanego wariantu fonemu $/ \mathrm{k} / \mathrm{z}$ fraz tak jak ty i park jesienny w wymowie czterdziestu ośmiu mówców pochodzących z obszaru dialektu małopolskiego, posługujących się standardową polszczyzną

\begin{tabular}{|c|c|c|c|c|c|c|}
\hline & & \multicolumn{5}{|c|}{ PLOZJA (taK jak ty, parK jesienny) } \\
\hline \multirow{6}{*}{ 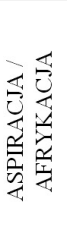 } & Odsetek realizacji & PREPALATALNE & MEDIO- (1) & MEDIO- (2) & POSTPALATALNE & PREWELARNE \\
\hline & PREPALATALNE & $36,2 \%$ & $25,5 \%$ & $9,4 \%$ & $1,3 \%$ & \\
\hline & MEDIOPALATALNE (1) & & $13,6 \%$ & $9,4 \%$ & $3,4 \%$ & \\
\hline & MEDIOPALATALNE (2) & & & & & \\
\hline & POSTPALATALNE & & & & $1,3 \%$ & \\
\hline & PREWELARNE & & & & & \\
\hline & & $36,2 \%$ & $39,1 \%$ & $18,8 \%$ & $6,0 \%$ & \\
\hline
\end{tabular}

Źródło: opracowanie własne.

W głównej tabeli kolorem szarym wypełniono pola odnoszące się do akustyczno-artykulacyjnie jednorodnych realizacji, a pogrubioną czcionką wskazano najliczniejsze realizacje o określonym miejscu artykulacji (z uwzględnieniem miejsca zwarcia i szczeliny). Dodatkowo, w dolnej tabeli podano łączny odsetek realizacji o odpowiednio, prepalatalnym, mediopalatalnym, postpalatalnym i prewelarnym miejscu artykulacji (z uwagi na miejsce zwarcia języka z podniebieniem).

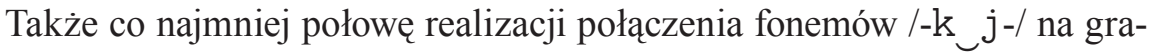
nicy wyrazowej, przeanalizowanych na podstawie nagrań z wydawnictwa Gwary polskie. Przewodnik multimedialny dla trzech obszarów dialektalnych: małopolskiego, wielkopolskiego i mazowieckiego, stanowiły przednie, prepalatalne lub mediopalatalne wymówienia (por. tab. 4. i bardziej szczegółowo, rys. 7.). 
Tab. 4. Procentowy udział wariantów realizacyjnych fonemu $/ \mathrm{k} / \mathrm{w}$ połączeniu $/ \mathrm{k} / \mathrm{j}$-/ w wymowie siedemdziesięciu pięciu mówców, reprezentujących trzydzieści dziewięć gwar i odpowiednio, cztery dialekty: małopolski, wielkopolski, mazowiecki i śląski

\begin{tabular}{|l|c|c|c|c|}
\hline \multicolumn{1}{|c|}{$\boldsymbol{k} \boldsymbol{j} / \boldsymbol{k} \boldsymbol{s}$} & D. MALOPOLSKI & D. WIELKOPOLSKI & D. MAZOWIECKI & D. ŚLASKI \\
\hline PREPALATALNE & $2 \mathbf{1 , 3}$ & $\mathbf{6 , 7}$ & 29,7 & 0,0 \\
\hline MEDIOPALATALNE (1) & $\mathbf{2 1 , 3}$ & $\mathbf{4 0 , 0}$ & $\mathbf{3 5 , 1}$ & 0,0 \\
\hline MEDIOPALATALNE (2) & 16,4 & 20,0 & 27,0 & 0,0 \\
\hline POSTPALATALNE & $\mathbf{2 7 , 9}$ & $\mathbf{2 6 , 7}$ & $\mathbf{8 , 1}$ & 0,0 \\
\hline PREWELARNE & 9,8 & $\mathbf{6 , 7}$ & 0,0 & $\mathbf{1 0 0 , 0}$ \\
\hline
\end{tabular}

Źródło: opracowanie własne.

W tabeli 4. pogrubioną czcionką wskazano najliczniejsze realizacje o określonym miejscu artykulacji, wyznaczonym w odniesieniu do miejsca zwarcia języka z podniebieniem.

Mimo różnic metodologicznych wyniki te odbiegają znacznie od zaprezentowanych przez M. Osowicką i A. Serowik (Osowicka, Serowik 2000). Analizowane w przywołanej pracy konteksty bibliotek jej i smak jabłek wymawiane przez dziesięciu mówców poddawane były głównie ocenie percepcyjnej. W przeważającej mierze, odpowiednio $90 \%$ i $85 \%$, oceniane były jako realizacje $\mathrm{z}$ twardym wariantem fonemu $/ \mathrm{k} /$. Pozostałe, nieliczne realizacje autorki zakwalifikowały jako półmiękkie (Osowicka, Serowik 2000: 79, 80). Z kolei interpretując wyniki uzyskane dla analizowanych przez autorkę fraz tak jak ty i park jesienny, należałoby stwierdzić, zgodnie z wynikami testów percepcyjnych, że aż 75,3\% realizacji zawiera miękkie [c], 18,8\% półmiękki wariant $\left[\mathrm{k}^{j}\right]$, przy zaledwie $6,0 \%$ realizacji $\mathrm{z}$ twardym $[\mathrm{k}]$. Kontekst /-k_j-/ należy w ogóle uznać za determinujący wyraźną palatalizację welarnego kontoidu - również w innych językach słowiańskich, np. chorwackim, serbskim, słoweńskim i słowackim, a nawet czeskim, jego artykulacja - opierając się na łącznych wynikach uzyskanych dla mówców głównie odmian standardowych - sytuowała się w przedniej części mediopalatum (niepublikowane dane autorki). 


\section{Podsumowanie}

Powstałe na skutek tzw. czwartej palatalizacji grupy ki/gi i kie/gie na Kaszubach wymawiane są z prepalatalnymi afrykatami [tढ] $]$ [d $\tilde{z}]$ ] Koneczna 1965: 147) lub zmiękczonymi afrykatami dziąsłowymi [t $\left.\int^{j}\right]$, [d $\left.{ }^{j}\right]$ (Sawicka 2007: 456). Na gruncie kaszubszczyzny nastąiło zatem nie tylko bardzo wyraźne uprzednienie welarnych, tj. ich silna palatalizacja, ale także zwarto-wybuchowe artykulacje przekształciły się w afrykaty, najprawdopodobniej - zgodnie z przedstawioną wcześniej hipotezą co do kolejnych faz palatalizacji welarnych - wchłaniając w swą strukturę najwyraźniej uprzednioną część wokoidu-następnika (Długosz-Kurczabowa, Dubisz 2001: 146-148).

W południowej odmianie standardowej polszczyzny, jak i w polszczyźnie uwarunkowanej dialektalnie rezultat czwartej palatalizacji jest słabszy - welarne uległy silnemu uprzednieniu, wykształcając w przeważającej mierze palatalne kontynuanty. Nie nastapiła natomiast integracja ich struktury w afrykaty, choć o procesie afrykatyzacji [c] - zważywszy na charakterystykę częstotliwościowo-czasową VOT - chyba można już mówić. Przedstawione w niniejszej pracy opisy akustyczne wariantów realizacyjnych fone$\mathrm{mu} / \mathrm{c} / \mathrm{i}$ ich interpretacja artykulacyjna pozwalają natomiast zdecydowanie zakwestionować postpalatum jako miejsce artykulacji podstawowego wariantu realizacyjnego /c/. Postpalatalne miejsce artykulacji wariantu podstawowego fonemu /c/ - jak się zwykło przyjmować w opisach polszczyzny zrównywałoby - także w percepcji, a przecież tak nie jest - rezultat czwartej palatalizacji z upodobnieniami w połączeniach typu ke/ge $i$ kę/ge oraz z pochodzącymi z nowych zapożyczeń $k e / g e$, a nawet z grupami typu $k s ́$ (por. charakterystyka uprzednionych wariantów realizacyjnych fonemu / k/ w prawostronnym kontekście $/ \varepsilon /$ - tab. 5., bardziej szczegółowo rys. 7.). Podobnie, południowa odmiana standardowej polszczyzny każe zweryfikować negatywnie tezę o odmiennej artykulacji kontoidu w wyrazach typu: taki, kiedy i makieta oraz autarkia i kiosk. Wreszcie, na poziomie fonetycznym struktura początkowej części wokoidu, następująca bezpośrednio po [c], nie daje podstaw do odmiennego traktowania, tj. $\mathrm{z}$ tzw. $j$ lub bez, kontekstów: kiedy i makieta, a także autarkia i kiosk. Oczywiste jest także, że przedstawiona charakterystyka fonetyczna wariantów realizacyjnych fonemu /c/ w ujęciach różnych metodologii fonologicznych może - o ile w ogóle jest uwzględniana - prowadzić do odmiennych opisów systemu współczesnej polszczyzny. 
Tab. 5. Procentowy udział wariantów realizacyjnych fonemu /k/ w prawostronnym kontekście /E/ w wymowie siedemdziesięciu dwóch mówców, reprezentujących trzydzieści sześć gwar i odpowiednio, trzy dialekty: małopolski, wielkopolski i mazowiecki

\begin{tabular}{|l|c|c|c|c|}
\hline \multicolumn{1}{|c|}{$\boldsymbol{k} \boldsymbol{e}$} & D. MALOPOLSKI & D. WIELKOPOLSKI & D. MAZOWIECKI & D. SLASSKI \\
\hline PREPALATALNE & $\mathbf{1 , 5}$ & 10,0 & 2,5 & 0,0 \\
\hline MEDIOPALATALNE (1) & 7,6 & 10,0 & 5,0 & 0,0 \\
\hline MEDIOPALATALNE (2) & 29,5 & 20,0 & 25,0 & 0,0 \\
\hline POSTPALATALNE & 43,9 & 40,0 & 32,5 & 0,0 \\
\hline PREWELARNE & 12,9 & 20,0 & 22,5 & 0,0 \\
\hline
\end{tabular}

Źródło: opracowanie własne.

Pogrubioną czcionką wskazano najliczniejsze realizacje o określonym miejscu artykulacji, wyznaczonym w odniesieniu do miejsca zwarcia języka $\mathrm{z}$ podniebieniem. 


\section{ILUSTRACJE}
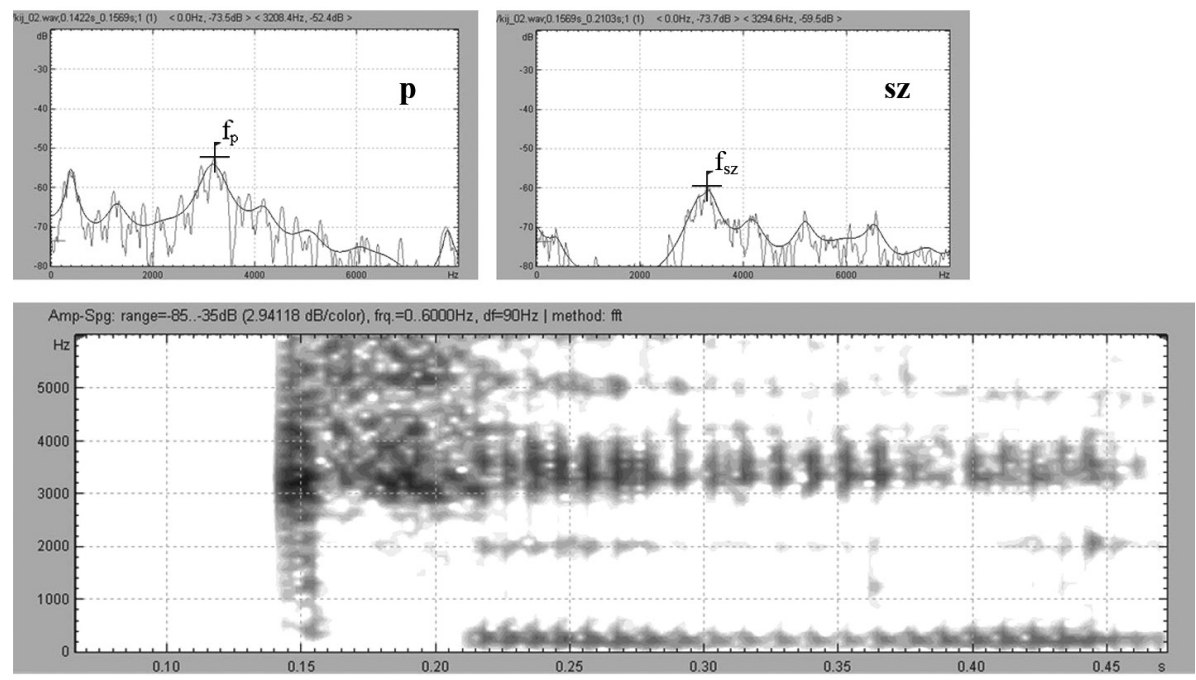

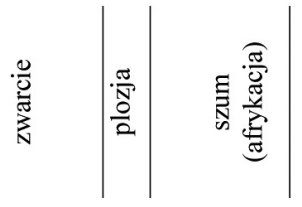

Rys. 1. Wariant realizacyjny fonemu /c/ w wyrazie kij

Źródło: opracowanie własne.

W górnej części rysunku - widma z zaznaczonymi maksimami dla plozji $\left(\mathrm{f}_{\mathrm{p}}\right.$; lewy górny rysunek) $\mathrm{i}$ komponentu szumowego, afrykacji $\left(\mathrm{f}_{\mathrm{sz}}\right.$; prawy górny rysunek); w dolnej części - spektrogram wyrazu kij z zaznaczonymi elementami struktury kontoidu: zwarciem, plozją i komponentem szumowym (afrykacją). 

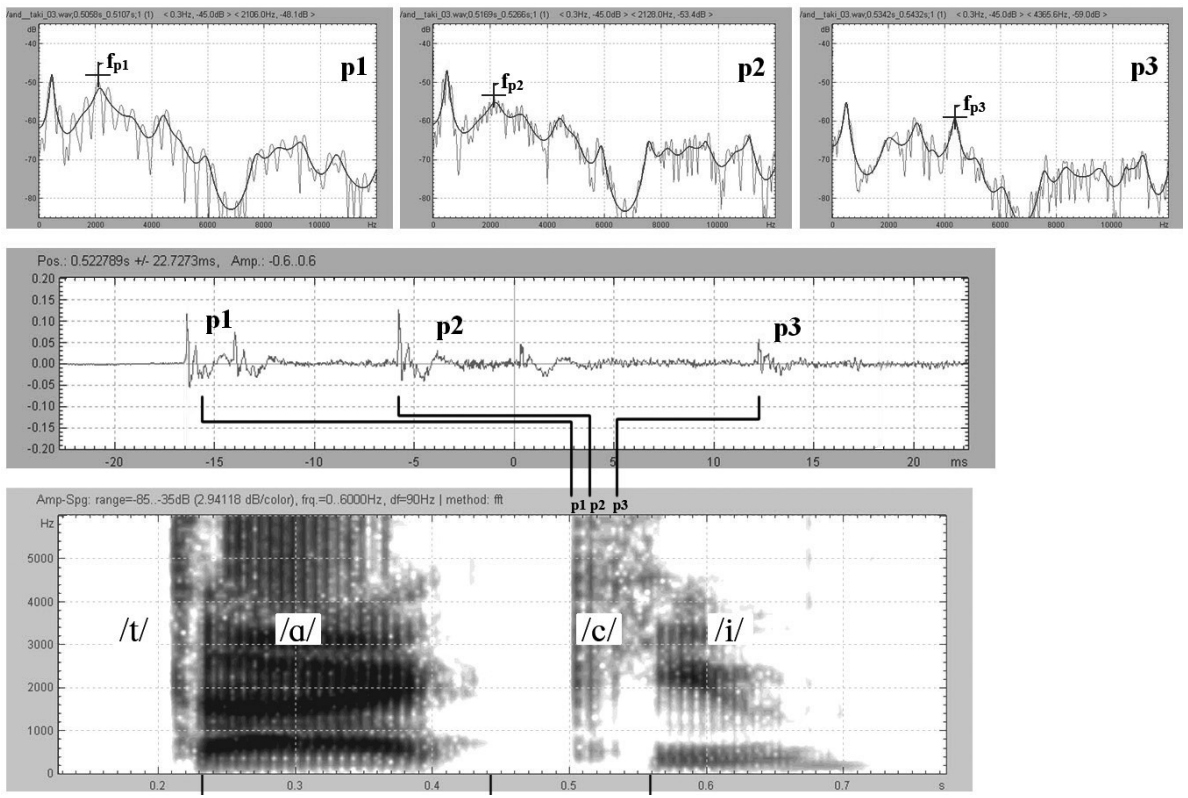

Rys. 2. Wariant realizacyjny fonemu /c/ z potrójną plozją z wyrazu taki

Źródło: opracowanie własne.

W górnej części rysunku - widma z zaznaczonymi maksimami dla pierwszej plozji (p1), drugiej (p2) i trzeciej plozji (p3); na rysunku środkowym - oscylogram z zaznaczonym segmentem plozji, obejmującej trzy plozje składowe; w dolnej części - spektrogram wyrazu taki z trzema plozjami składowymi; z uwagi na detale nie zachowano skali czasowej pomiędzy poszczególnymi rysunkami. 


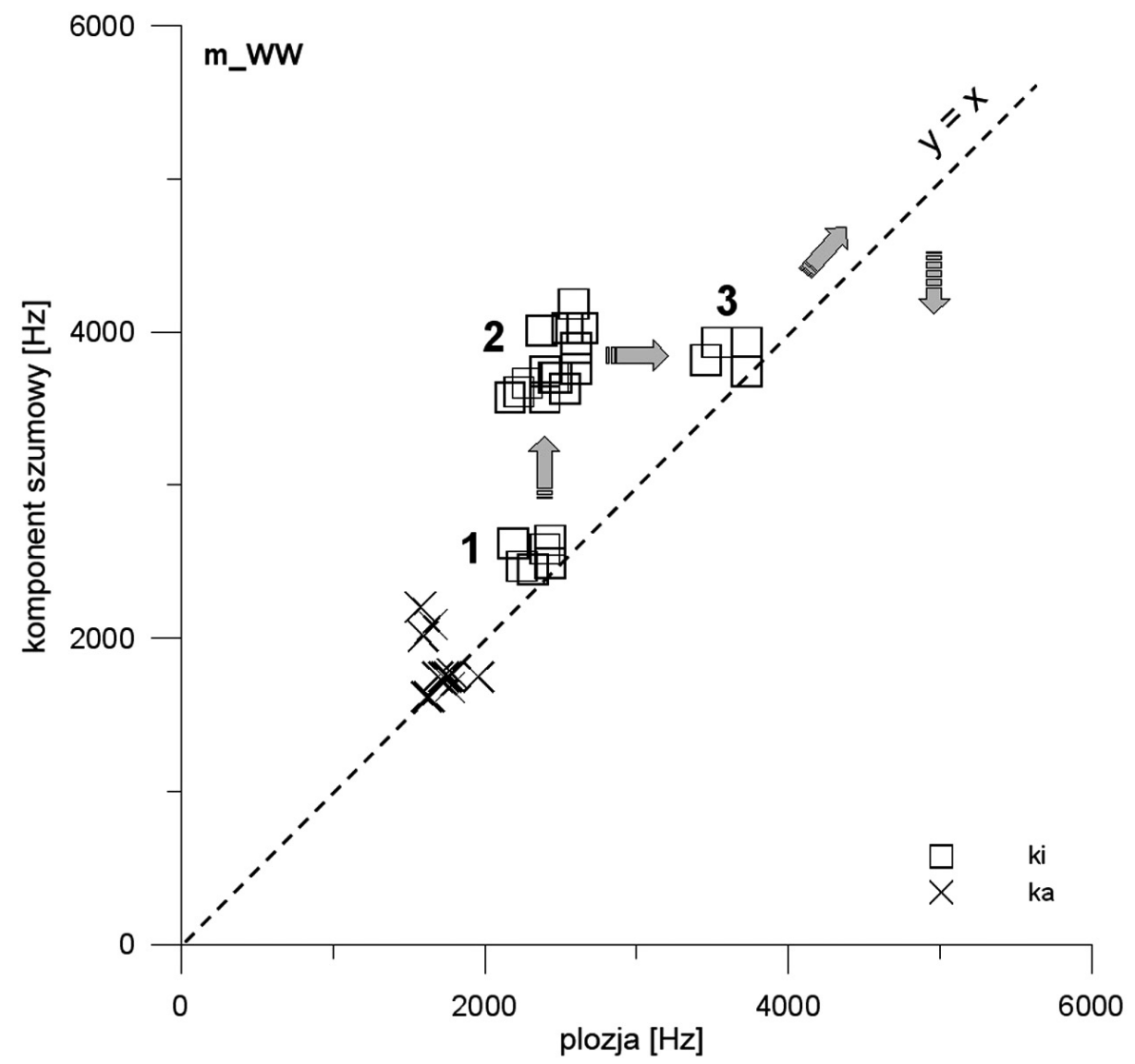

Rys. 3. Zróżnicowanie akustyczno-artykulacyjne realizacji fonemu /c/ w prawostronnym kontekście /i/ z zaznaczeniem kierunku i periodyzacji dotychczasowego i ewentualnego dalszego rozwoju wariantów realizacyjnych /c/

Źródło: opracowanie własne.

Jako punkt odniesienia na rysunku uwzględniono realizacje $[\mathrm{k}] \mathrm{w}$ prawostronnym kontekście [a]. Wzdłuż prostej $\mathrm{y}=\mathrm{x}$ sytuują się realizacje jednorodne. 

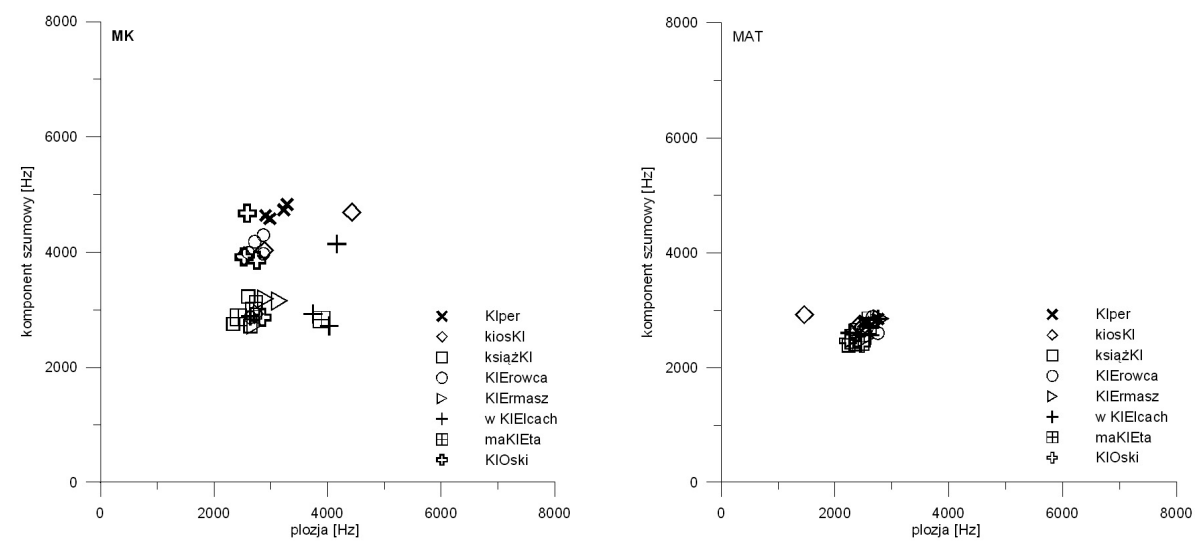

Rys. 4. Zróżnicowanie akustyczno-artykulacyjne realizacji fonemu /c/ z uwagi na prawostronny kontekst wokaliczny, wskazujące na brak systemowego wpływu następującej po kontoidzie samogłoski na jego artykulację; przedstawiono wymowę dwóch mówców w odniesieniu do leksemów występujących w słowniku języka polskiego

Źródło: opracowanie własne. 

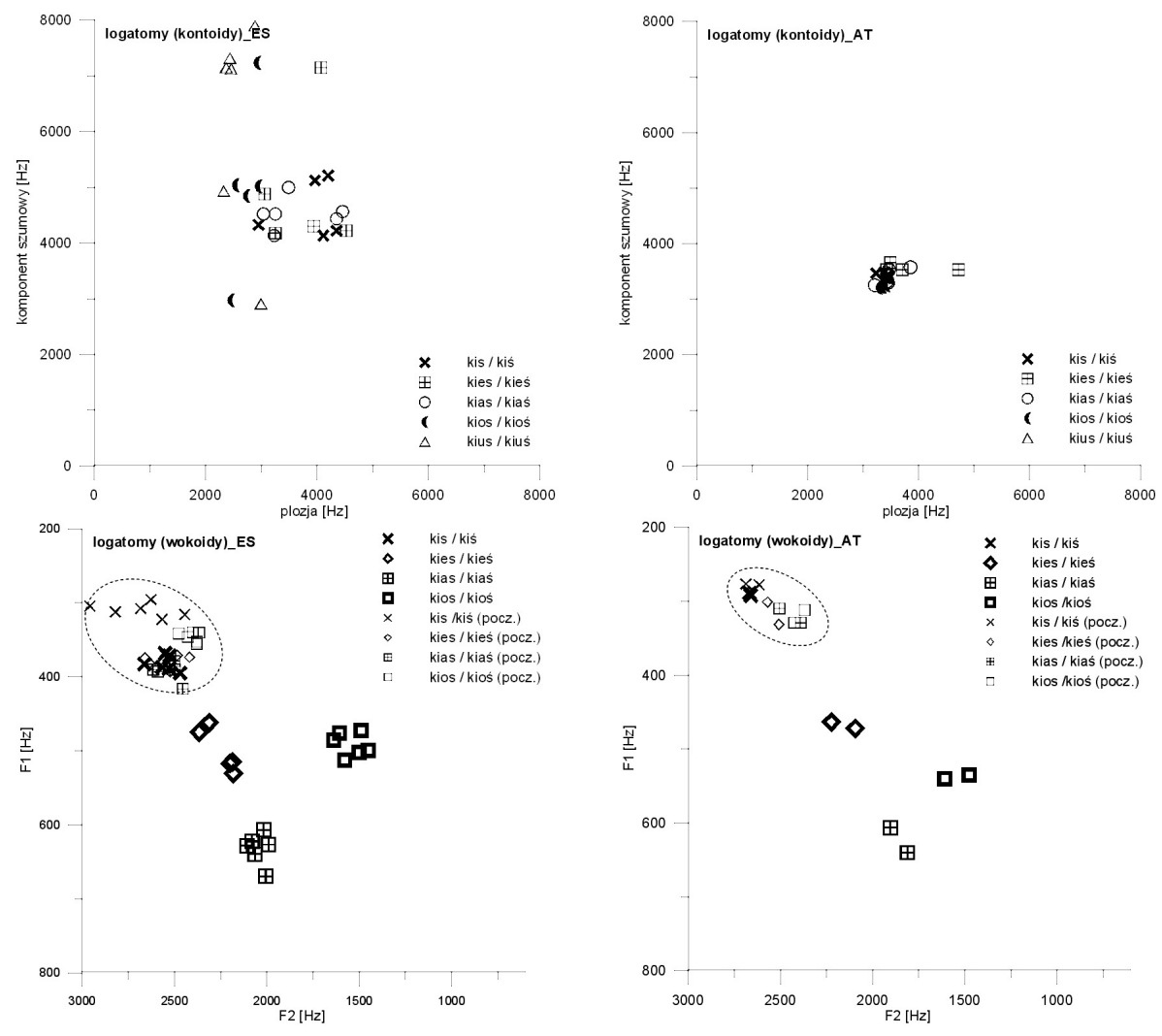

Rys. 5. Charakterystyka akustyczna realizacji fonemu /c/ w zróżnicowanym prawostronnym kontekście wokalicznym (górne rysunki) z uwzględnieniem charakterystyki wokoidów, w tym ich początkowej części (dolne rysunki); przedstawiono wymowę dwóch mówców w odniesieniu do logatomów o strukturze /cVs/ i /cV6/

Źródło: opracowanie własne. 

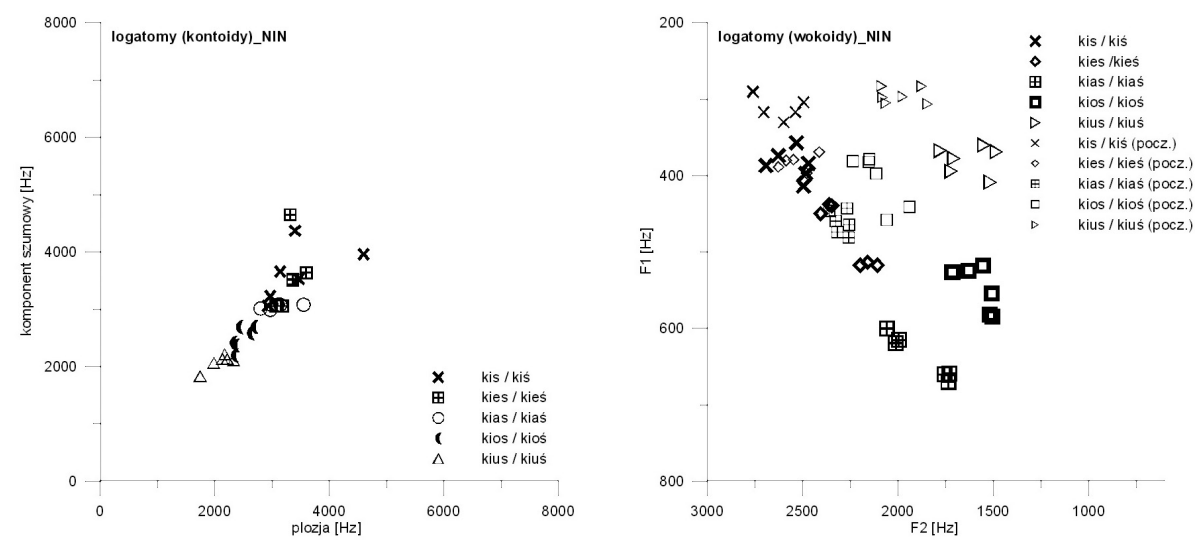

Rys. 6. Charakterystyka akustyczna realizacji fonemu /k/ w zróżnicowanym prawostronnym kontekście wokalicznym (po lewej stronie) z uwzględnieniem charakterystyki wokoidów, w tym ich początkowej części (po prawej stronie); przedstawiono wymowę jednego rodzimego użytkownika języka rosyjskiego w odniesieniu do logatomów o strukturze /cVs/ i /cVø/

Źródło: opracowanie własne. 
$k i$
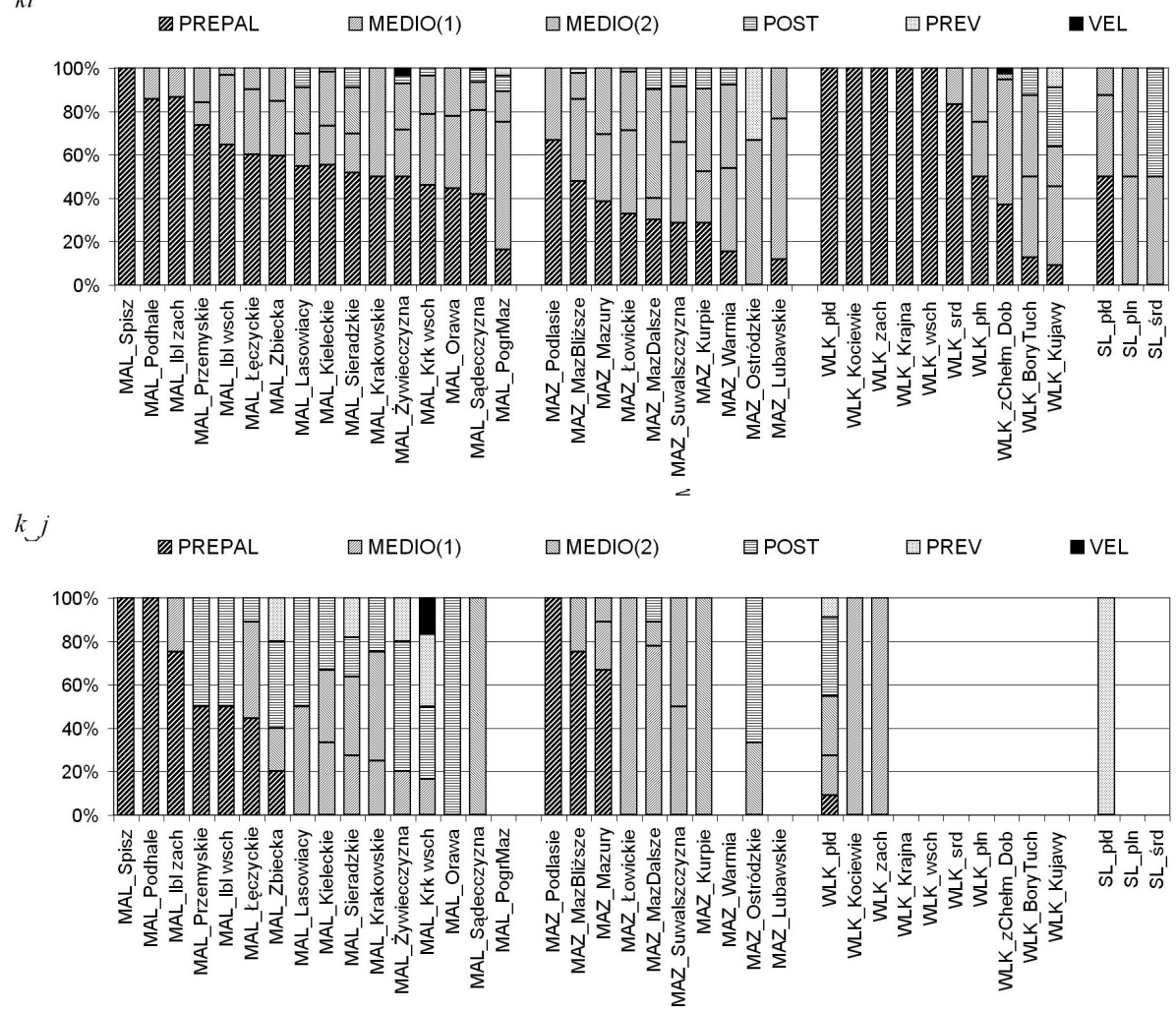

ke

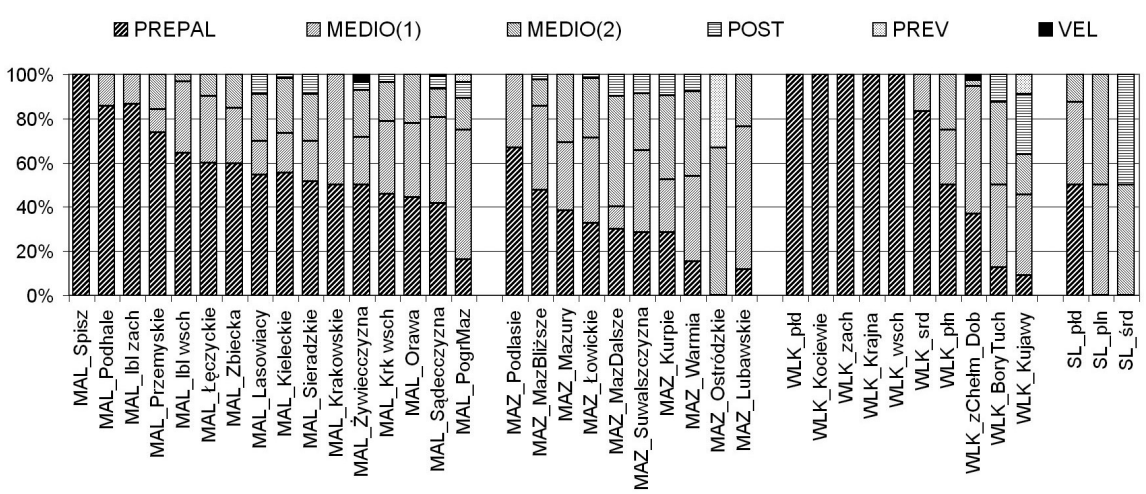

Rys. 7. Procentowy udział wariantów realizacyjnych fonemów /c/ w prawostronnym kontekście /i/ oraz wariantów /k/ - przed / $/ \varepsilon /$, na granicy wyrazowej /-k_j-/ i wewnątrz wyrazu /-k6-/ w wymowie siedemdziesięciu pięciu mówców z uwzględnieniem dialektu i gwary, w których kształtowały się ich mechanizmy artykulacyjne

Źródło: opracowanie własne. 


\section{Bibliografia}

Chо T., LAdefoged P., 1999, Variation and universals in VOT: evidence from 18 languages, Journal of Phonetics 27, s. 207-229.

DŁugosz-Kurczabowa K., Dubisz S., 2001, Gramatyka historyczna języka polskiego, Warszawa: Wydawnictwa Uniwersytetu Warszawskiego.

Dıuska M., 1986, Fonetyka polska. Artykulacje głosek polskich, Warszawa-Kraków: Państwowe Wydawnictwo Naukowe.

DukiEwicz L., 1996, Warunki skuteczności badań zmierzających do fonetycznej lub fonologicznej klasyfikacji języków, Acta Universitatis Nicolai Copernici Studia Slavica I, s. 25-29.

FANT G., 1960, Acoustic theory of speech production with calculation based on X-ray studies of Russian articulations, The Hague: Mouton \& Co Publisher.

JASSEM W., 1973, Podstawy fonetyki akustycznej, Warszawa: Państwowe Wydawnictwo Naukowe.

JeSSEN M., 2002, An acoustic study of contrasting plosives and click accompaniments in Xhosa, Phonetica 59, s. 150-179.

Karaś H., Gwary polskie. Przewodnik multimedialny [on line], www.gwary polskie. uw.edu.pl, [5.07.2010].

Keating P. A., Lahiri A., 1993, Fronted velars. Palatalized velars, and palatals, Phonetica 50, s. 73-101.

Keating P. A., Mikoś M. J., Ganong W. F., 1981, A cross-language study of range of voice onset time in the perception of initial stop voicing, Journal of Acoustical Society of America 70 (5), s. 1261-1271.

KoneCZna H., 1934, Studjum eksperymentalne artykulacji głosek polskich, Warszawa (odbitka z Prac Filologicznych t. XVI).

Koneczna H., 1965, Charakterystyka fonetyczna języka polskiego, Warszawa: Państwowe Wydawnictwo Naukowe.

Koneczna H., ZAWADOWSKI W., 1951, Przekroje rentgenograficzne glosek polskich, Warszawa: Państwowe Wydawnictwo Naukowe.

ŁoBACz P., 1982, Interpretacja fonologiczna palatalności w języku polskim na podstawie analizy spektrograficznej, w: J. Maciejewski (red.), Z zagadnień fonetyki i fonologii wspótczesnego języka polskiego. Księga referatów ogólnopolskiej konferencji w Toruniu, 27-29 listopad 1978 r., Toruń: Uniwersytet Mikołaja Kopernika, s. 93-101.

Łobacz P., 1989, Psychometryczne metody klasyfikacji elementów segmentalnych mowy, Warszawa: Instytut Podstawowych Problemów Techniki PAN.

Łobacz P., 1996, Polska fonologia dziecięca. Studia fonetyczno-akustyczne, Warszawa: Wydawnictwo Energeia. 
Moosmüller S., 2007, Vowels in Standard Austrian German. An acoustic-phonetic and phonological analysis (habilitationsschrift, Vienna University), Vienna (manuskrypt).

Moosmüller S., Ringen C., 2004, Voice and aspiration in Austrian German plosives, Folia Linguistica XXXVIII/1-2, s. 43-62.

Osowicka M., Serowik A., 2000, Wstępna analiza palatalności asymilacyjnej w języku polskim. Pozycja przed [i] oraz [j]. Pozycja przed palatalnymi oraz palatalizowanymi spółgłoskami, Acta Universitatis Nicolai Copernici Studia Slavica IV, s. $67-102$.

Osowicka-Kondratowicz M., Serowik A., 2007, Palatalność asymilacyjna w języku polskim, w: I. Sawicka (red.), Komparacja systemów i funkcjonowania wspótczesnych języków słowiańskich. Fonetyka/Fonologia, Opole: Uniwersytet Opolski Instytut Filologii Polskiej, s. 61-102.

Ostaszewska D., Tambor J., 2000, Fonetyka i fonologia wspótczesnego języka polskiego, Warszawa: Wydawnictwo Naukowe PWN.

Recasens D., Fontdevila J., Pallarès M. D., 1994, An electropalatographic investigation of segmental complexity in alveolopalatal consonants, Catalan Working Papers in Linquistics, vol. 3.2, s. 71-96.

Recasens D., Espinosa A., 2009, Acoustics and perception of velar softening for unaspirated stops, Journal of Phonetics 37, 189-211.

RoJcZYк A., 2009, Parametr VOT w języku polskim i angielskim. Badanie percepcji, LingVaria IV (1), 29-47.

SAwicka I., 1995, Fonologia, w: H. Wróbel (red.), Gramatyka wspótczesnego języka polskiego. Fonetyka i fonologia, Kraków: Wydawnictwo Instytutu Języka Polskiego PAN, s. 105-195.

SAwicka I., 2007, Palatalność, w: I. Sawicka (red.), Komparacja systemów i funkcjonowania wspótczesnych języków stowiańskich. Fonetyka/Fonologia, Opole: Uniwersytet Opolski - Instytut Filologii Polskiej, s. 21-28.

Sawicka I., Grzybowski S., 1999, Studia z palatalności w językach słowiańskich, Toruń: Wydawnictwo Uniwersytetu Mikołaja Kopernika.

Stevens K., 2000, Acoustic phonetics, Cambridge, Massachusetts, London, England: The MIT Press.

TRAwiŃSKA A., 2009, Zastosowanie do celów biometrycznych analizy mowy wykonywanej przy użyciu narzędzi inżynierii biomedycznej, w: R. Tadeusiewicz, P. Augustyniak (red.), Podstawy inżynierii biomedycznej, Kraków: Wydawnictwa AGH, t. 1, s. 253-268.

WierzchowsKa B., 1980, Fonetyka i fonologia języka polskiego, Wrocław-Warszawa-Kraków-Gdańsk: Zakład Narodowy im. Ossolińskich, Wydawnictwo PAN. 


\section{A phonetic description of /c/ in contemporary Polish} ( s u m mary)

The paper discusses the acoustic variants of the phoneme/c/, together with the appropriate articulatory interpretation and auditory perception assessment. The acoustic correlates and articulatory interpretation are based upon the theory of speech production introduced by G. Fant and developed by K. Stevens.

The acoustic data for standard Polish provide evidence against describing the primary variant of $/ \mathrm{c} /$ as a postpalatal sound. The collected data clearly demonstrate that the place of articulation of $/ \mathrm{c} /$ sounds is further in the front part of palate, i.e. prepalatum. The same conclusion might be draw on cumulative data for dialectal varieties of Polish. 